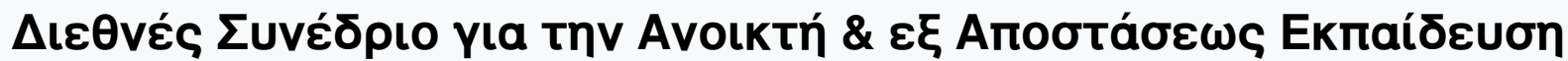

Tón. 5, Ap. 1A (2009)

Open and Distance Education for Global Collaboration \& Educational Development

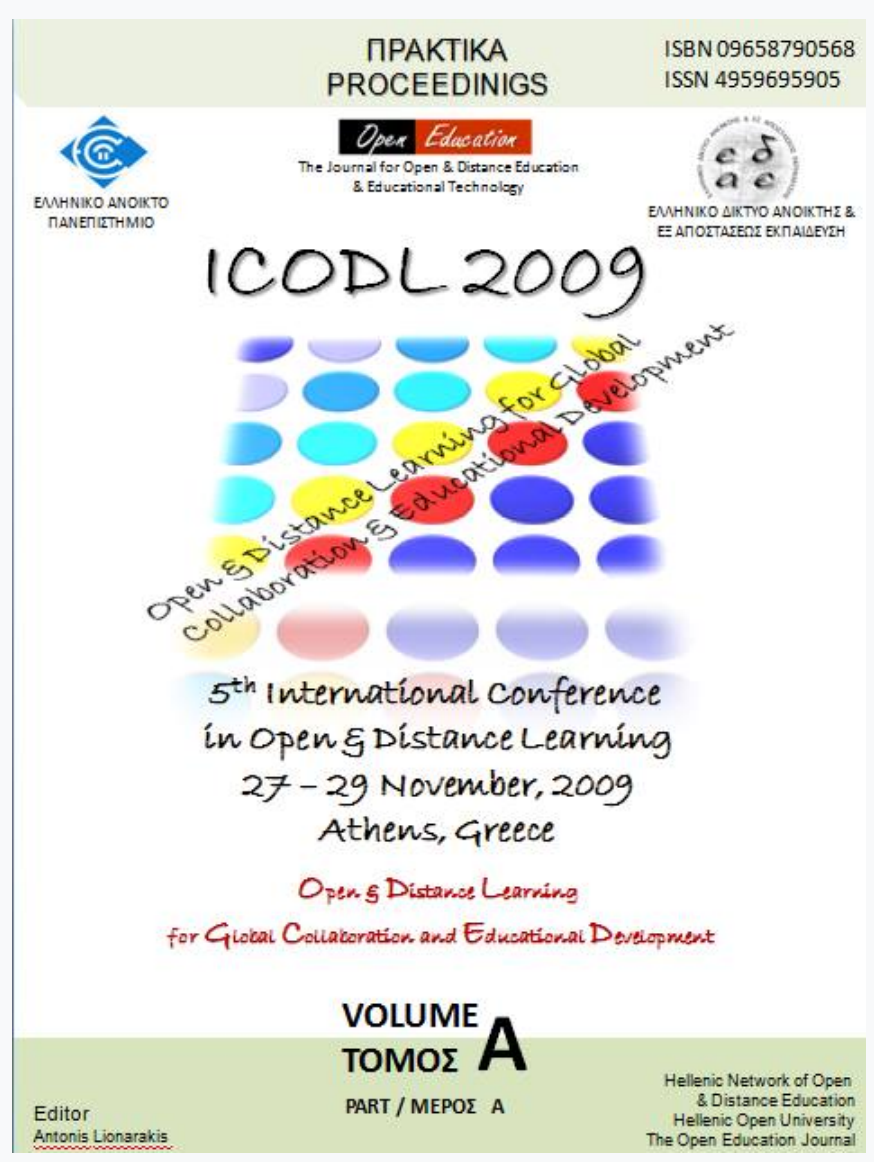

The Contribution of E-Learning to the Implementation of a Lifelong Learning Perspective in Higher Education

Melanie LAHNE, Michael KERRES

doi: $10.12681 /$ icodl. 482 


\title{
The Contribution of E-Learning to the Implementation of a Lifelong Learning Perspective in Higher Education
}

\author{
Melanie LAHNE \\ University of Duisburg-Essen \\ Educational Sciences \\ Media Didactics and Knowledge Management \\ Scientific Associate \\ Dr. phil. \\ melanie.lahne@,uni-due.de
}

\author{
Michael KERRES \\ University of Duisburg-Essen \\ Educational Sciences \\ Media Didactics and Knowledge Management \\ Head of Chair \\ Prof. Dr. \\ michael.kerres@uni-duisburg-essen.de
}

\begin{abstract}
The educational mandate of universities in Germany is constricted to the short life span between high school graduation (Abitur) and career entry. This prevents an adequate response to the challenges of "lifelong learning". This paper discusses the implied orientation of study programs towards ,the normal student' and describes the consequences of a lifelong learning perspective at universities, which acknowledges the diversity of students and offers respective programs.

Furthermore the potential of e-learning within this context will be highlighted. It is a tool to make the organization of study more flexible and to create open programs for target groups with different requirements, i.e. for students with professional experience and employment. Additionally, the authors introduce the co-operative project „Study and Work: Aspects of Success of Lifelong Learning in Higher Education (STUBE)", which is conducted within the educational research grant program of the Federal Ministry of Education and Research (BMBF). Here the participating universities develop and apply strategies to design study programs within the paradigm of lifelong learning.
\end{abstract}

\section{The present status of lifelong learning at universities}

„Lifelong learning“ presents a central goal for the development of the educational system (Faulstich, 2003). It is the process of knowledge acquirement and reorganization, which continues throughout the entire life. Thereby education becomes a process of self-responsible creation of an individual learning biography. This can not be realized through a program structure that is based on institutional expectations but through a program structure that is based on prerequisites and demands of learning individuals (Bloch, 2006: 8).

But the educational system in Germany is traditionally structured in institutional segments, which are designed only for learning in a certain part of the life span. Universities therefore implicitly constrict their educational mandate to learning in the short time between high school graduation and career entry (Klink, 2001). Hanft and Knust (2007) characterize the system of higher education in Germany by the term „Ausrichtung am 'Normalstudierenden'“, which means orientation towards the 'normal student'. 
This discussion should be considered within the context of societal changes within the educational system and the employment system: More and more people decide to study after a vocational training and a time of first professional experience. More and more people will enter a career already after a Bachelor Degree, from where they later - might want to continue their scientific education. If they want to continue working during their studies they depend on flexible university programs. At the same time those students who have professional experience expect a learning environment that considers their competence and experience in terms of content and methods.

Winter (2009) states that the Bologna process creates options for the opening of universities towards lifelong learning, but he also mentions the discrepancy between study program organization and prerequisites of lifelong learning (see also DGWFEmpfehlungen, 2005: 2). Furthermore belong to a growing target group more and more students who want to take part in continuing professional education programs in spite of special life conditions, like students who take care of children or relatives in need of care. This target group requires flexible program structures, too.

\section{International perspectives}

As mentioned before, study programs in Germany are oriented towards 'normal students' in terms of content as well as organization. The underlying idea is that students start their studies after high school graduation and attend to it completely full-time.

If we consider these implications in detail the following aspects appear:

- Students enter university after high school graduation! But statistics show:

- The average age of students is 25 years.

- $1 / 10$ of all students are older than 25 years when they enter university.

- $64 \%$ of all students have professional experience when they enter university.

- $25 \%$ of all students have finished a vocational training when they enter university.

○ $72 \%$ of all students are characterized as „Studienverzögerer“ (delayed students) with a waiting time more than 4 months (average 21 months).

- Students attend to their studies completely full-time. They can organize their time autonomously. But statistics show:

○ $66 \%$ of all students work besides studying.

- $25 \%$ of all students do not study full-time ( $25 \mathrm{~h} /$ week or less)

○ $7 \%$ of all students are parents ( $8 \%$ of female students / $6 \%$ of male students)

Source: Deutsches Studentenwerk (German Student Union), 2008 / HIS, 2005 / Statistisches Bundesamt (Federal Statistics Office), 2005

In international discussions one can find the term „non-traditional students“, but the criteria for a definition are rather confusing. The National Center for Education Statistics in the USA states the following criteria: The student (a) works for at least 35 hours per week, (b) studies part-time, (c) takes care of children or other relatives, (d) is single parent, (e) is financially independent, (f) starts his/her first study in the year 
after high school graduation or $(\mathrm{g})$ enters higher education through an alternative access.

It is obvious that a definition as broad as this leads to a statistic of $73 \%$ and more „,non-traditional“" students in the country, and that this concept can be difficult to use for research purposes (see also Pechar and Wroblewski, 1998). Nevertheless one can state that given the fact of a high competition universities in other countries already address this group of students in a systematic way and search for strategies to develop adequate programs for a diverse student body (Röbken, 2007). The international comparison study of Hanft and Knust (2007) shows the variety of possible organization and development of continuing education at universities.

The Open University in England is with approx. 180.000 students the largest university in Europe. Here $70 \%$ of all students attend study programs besides work. The university program is no longer divided into initial study and continuing education and for statistics a distinction is rather made between full-time and parttime study programs. Widening participation, continuing professional development and demand orientation are basic elements of the university's objectives (Geldermann and Schade, 2007). In Finland the number of students in continuing education at universities is higher than the number of 'traditional' students. From an international comparative perspective the country is leading regarding the investment in higher and vocational education (Zawacki-Richter and Reith, 2007).

According to The Standing Conference of the Ministers of Education in Germany $(\mathrm{KMK})^{1}$ - decision from September 18, 2008 - a distinction besides BachelorPrograms as 'initial studies' is made between Master programs as follow-on, nonfollow-on and continuing education programs. Continuing education programs are characterized by the policy of official recognition of professional competences. At this time (state April 2009) only 450 of all 14.000 study programs are continuing education programs (Master). Only 272 of them are accredited. Only 270 study programs can be completed as part-time studies, and 142 are distance learning programs (hochschulkompass.hrk.de / own analysis).

In spite of a growing number of continuing education offerings at universities the participation in scientific continuing education in Germany is low: According to the „Berichtssystem Weiterbildung“ des BMBF (report system of the Federal Ministry of Education and Research) the participation from 1991 until 2003 was between 3\% and $6 \%$ of the general as well as of the vocational continuing education. This stands in contrast to countries like Finland, in which universities contribute $50 \%$ and more to the continuing education of the country (Zawacki-Richter and Reith, 2007). However, one must also consider that the demand for continuing education in Germany is also covered by other institution, which often co-operate with universities regarding development and implementation of programs.

\section{E-learning as a lifelong learning tool}

To pursue a lifelong learning strategy at universities has far reaching implications. This applies to the definition of the educational mandate of universities, to the study program organization, and to the application of methods and media. Schuetze and Slowey (2002) have contrasted implications of the traditional mode and of a lifelong learning perspective, in which the interdependence of the single factors can be seen. Thus the request for part-time studies can be answered with a variety of media 
application for self-learning and co-operative settings. The request for flexible learning locations can be answered with synchronic and a-synchronic communication means.

\begin{tabular}{|l|l|}
\hline Traditional Mode & Lifelong Learning Perspective \\
\hline Limited access & Open access \\
\hline $\begin{array}{l}\text { Admission through higher } \\
\text { education entrance qualification }\end{array}$ & $\begin{array}{l}\text { Official recognition of professional } \\
\text { competences }\end{array}$ \\
\hline For younger students & For all ages \\
\hline Selection by achievement & Learning possibilities for everyone \\
\hline Full-time & Full-time, part-time, evening classes etc. \\
\hline localized & $\begin{array}{l}\text { Distance Learning, virtual study, self-organized } \\
\text { learning }\end{array}$ \\
\hline $\begin{array}{l}\text { linear study programs with final } \\
\text { examination }\end{array}$ & Modularization, credit point system \\
\hline Subject-oriented study & Competence-oriented, solution-oriented study \\
\hline Degree-oriented & flexible \\
\hline Initial academic education & Learning-process-oriented \\
\hline uniform university system & differentiated university system \\
\hline
\end{tabular}

From: Schuetze / Slowey (2002): 435

Digital media offer the possibility to create a flexible study organization and to deliver content to a large audience. The application of new media - especially in combination with an institutional system that officially recognizes professional competences - can realize a university program, which in terms of space and time is generally adjusted to target groups with diverse interests, prerequisites, and backgrounds. This can be realized as an initial study, continuing education, an individually organized full-time study or a part-time study. Such educational programs are flexible enough to answer the demand for diverse teaching and learning settings as required in lifelong learning processes (Lahne, 2008).

But a sustainability of e-learning implementation is possible only with far-reaching changes within an institution. It is apparent that even with substantial funding elearning can not be established automatically. The introduction of single projects does not guarantee their constancy nor does it initiate other projects. It is important to establish respective arrangements in different departments of the university - more than it was pursued in prior development projects (Kerres, 2005).

Zawacki-Richter (2005) points out the importance of e-learning at Dual Mode Institutions, which offer face-to-face programs and distance learning at the same time. The structural similarity of e-learning and distance learning allows the institutions to use long-time experience with alternative educational methods for e-learning implementation, which exist as a result of the interaction with distance learning procedures. This applies to the attitude of participants, strategies, support structures, administration, and departments, which present a complex system that is prepared for the needs of distance learning students. That way respective institutions have developed a sense for programs and media applications that address different target groups and their special needs. 
In Germany it is the Technical University Darmstadt that is known for its goal to become a „Dual Mode-University“. Dual Mode here means the combination of online and face-to-face teaching (blended learning) but not as an instrument for the development of innovative study programs for diverse target group. The mission of the university is to bring e-learning and face-to-face teaching in a didactically meaningful and balanced relation. ${ }^{2}$

\section{4. "Study + Work": The sustainable implementation of lifelong learning at three German universities}

Within the co-operative project „Study and Work: Aspects of Success of Lifelong Learning in Higher Education (STUBE)", which is funded by the Federal Ministry of Education and Research (BMBF), the University Duisburg-Essen, the University Oldenburg and the Technical University Dortmund address the problems of:

- How to consider prerequisites, experiences, and needs of working people and postgraduates in study programs, and

- How to include them in initial and continuing education programs.

In this combined research and development program the conditions of lifelong learning at the participating universities will be analysed regarding strategy, organization, management, didactics, and media. Furthermore, based on the results of the analysis innovation projects for the development of a lifelong learning strategy at the institutions will be implemented. The question is, which challenges universities have to face when they consistently open their program to people who want to stay in their career during their studies. Regarding a consistent application and sustainable implementation of a lifelong learning agenda the basic step of program planning will be a main focus. The goal is a change of perspective from continuing education as an additive program to an integrated approach, in which already the regular study programs are open for working professionals.

\subsection{Research phases}

The first research phase of data collection among students with a questionnaire is geared to the questions: Which concrete expectations do university students have? Which expectations and experiences do working students have? Which teaching forms, services, support structures, and spaces of autonomy are expected? Afterwards case studies of the three universities will be conducted, in order to clarify in which way they already have established lifelong learning conditions, and where strengths and weaknesses, chances and risks lie. The results of the analysis will present information about existing options for working professionals, about the procedure of their development and conduction, about marketing, institutional organization, medial support, strategic positioning of the institutions as well as about the goals of existing offerings. Furthermore, case studies at three additional universities in England (Open University), Canada (University of British Columbia) and Finland (Palmenia Centre, 
University of Helsinki) will be conducted, which are already successful in pursuing a lifelong learning strategy with e-learning.

Based on the case study results the focus and the goal of the innovation phase will be defined together with stakeholders of the universities in following workshops. Here participants of the research group will accompany the process with scientific advice, in order to elaborate, which conditions on-site can be employed to implement developed and suggested projects for working people as well as which conditions must be established and which barriers must be overcome. 


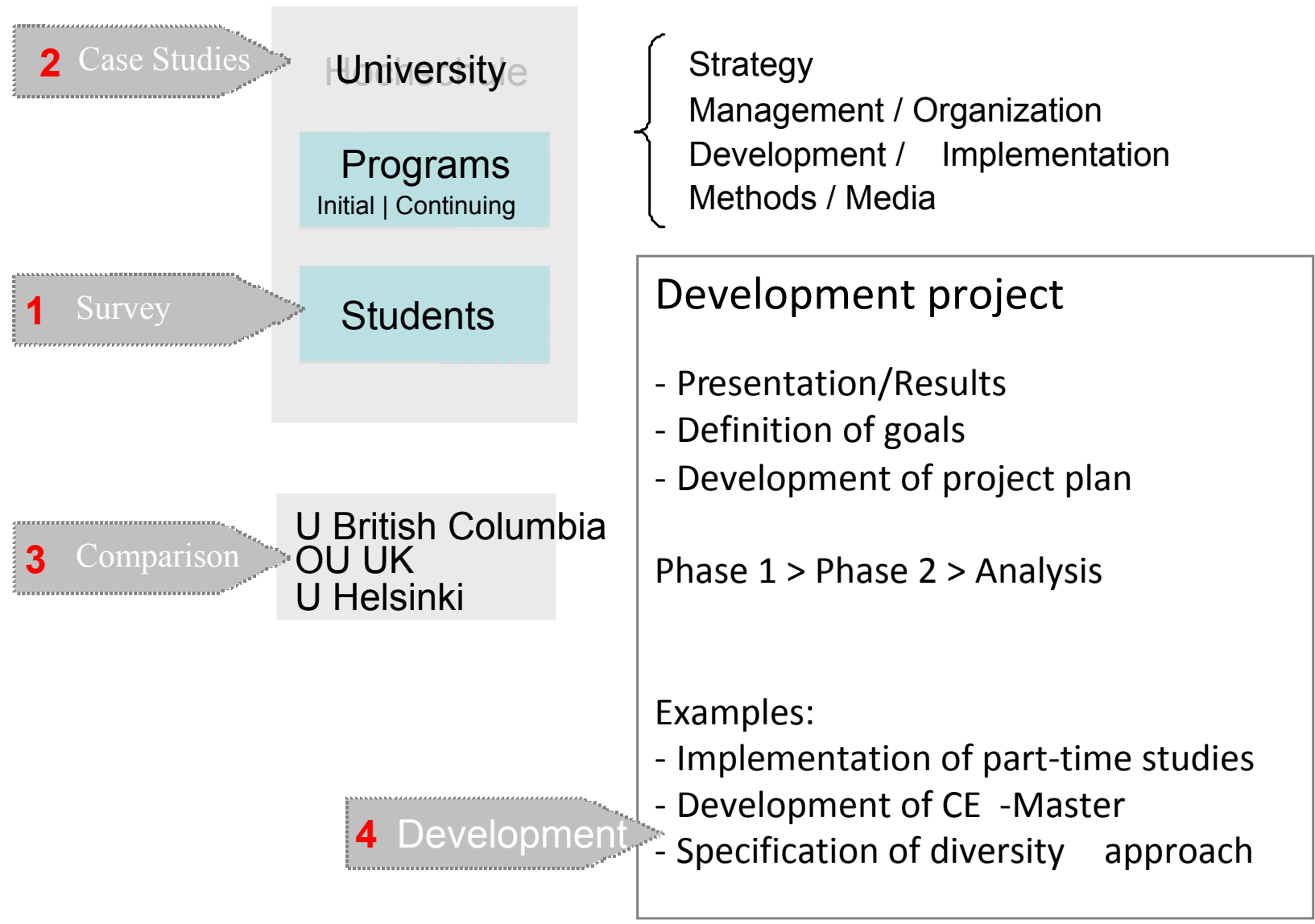

\subsection{Innovation phase}

During the innovation phase projects will be initiated, which are geared to support the three German universities in the development of more study programs for working people and in the adjustment of their educational mandate to this target group. Each university develops and pursues its own goal.

The University of Duisburg-Essen determines in its university development plan the goal to create study programs for continuing education purposes, also with e-learning, and to develop part-time study programs, which are adjusted - as well with e-learning - to working students. Here the application of media supported programs and the integration of online elements in curricula will be promoted systematically. Models of Change Management (e.g. Kerres and Stratmann (2007)) present a conceptual basis for this process of change at the institution. This university development process is centred on the mission to explore the potential of possible innovation strategies for success, to use the potential of lifelong learning programs for the strategic positioning as well as to intensify the co-operation between science, service centres and administration. The innovation phase therefore intends to initiate a process that tries to overcome typical barriers for change (see also DGWF-Empfehlungen, 2005: 5). 


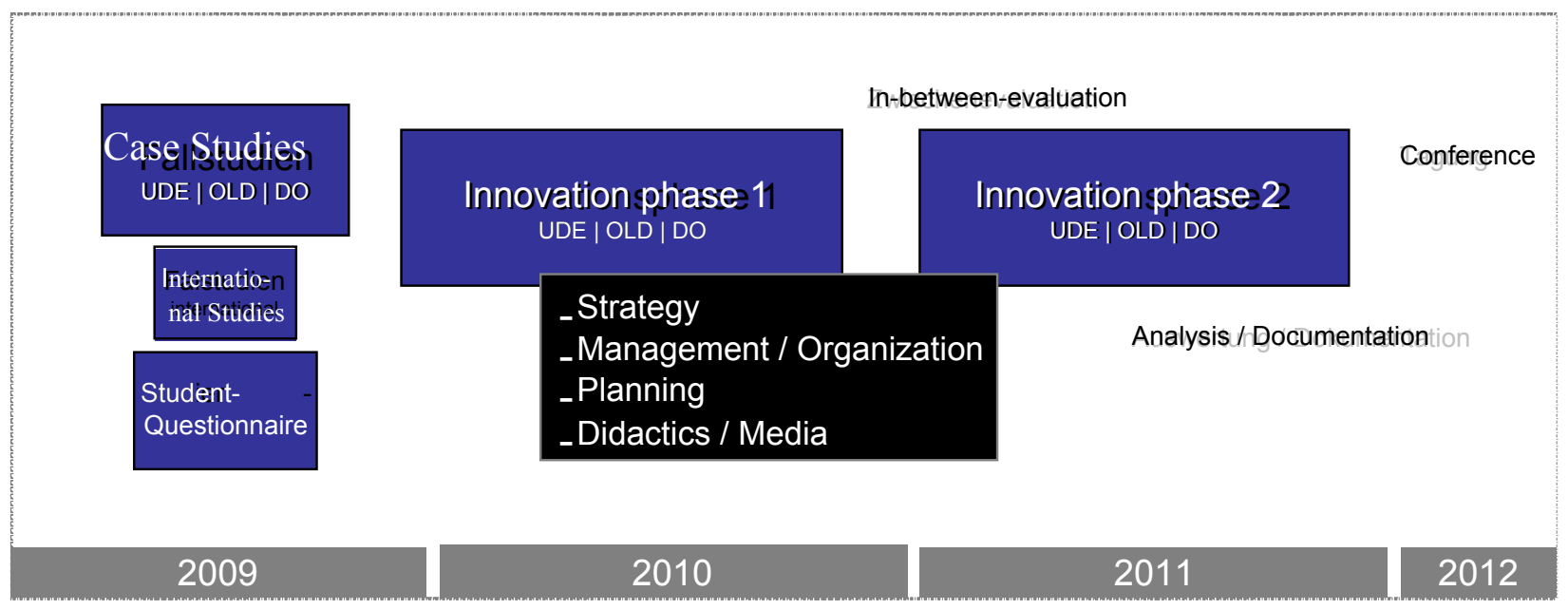

\section{Prospects}

The implications of a lifelong learning perspective for universities are considerably more profound than just the expansion of continuing education programs. It is important to redefine the educational mandate of universities basically, and thus to redefine the target group of the university program in general (see also Jongbloed, 2001). But it is not a question of quantitative expansion and replacement of established providers of continuing education. It is a question of design and orientation of programs in terms of content, methods and media.

The orientation towards expectations, needs and experiences of people with professional experience and/or with a career besides their studies require different teaching and learning approaches. One postulation is the official recognition of professional competences. First of all this means the recognition of competences in the form of awarding credit points but also in the form of a didactical adjustment of teaching and learning arrangements, which consistently integrate experiences of students, initiate reflexion of experiences and encourage new experiences. This process can be oriented towards the 'Inquiry Process' of experiential learning according to Dewey. Kerres and de Witt (2004) show how to apply this approach to the design of media-supported programs. Those programs offer the possibility of genuine learning situations through the application of multi-media as well as the creation space, in which co-operative exchange processes can be initiated (e.g. with web 2.0 tools, see Kerres, 2008).

Another postulation is the consideration of the diversity of learning prerequisites and conditions in study programs. Media-supported programs present an important contribution to a diversity strategy that aims to include and accentuate the diversity of people as a program quality. Instead of realizing programs that are oriented towards 'normal students' it is more than just adequate regarding diverse societal and 
educational conditions to respond to the demand for flexible teaching and learning settings with e-learning. Here all varieties of synchronic and a-synchronic communication play a key role and should be combined with face-to-face settings in one didactic concept. Media can especially provide the flexibility in terms of learning locations; flexibility in terms of time should be provided through new forms of parttime studies. This has to be considered more profoundly than in prior solutions, which are characterized by simply reducing study time to $50 \%$ of courses. But a diversity approach would be based on a study design, in which a broad variety of study forms is employed, which then can be adjusted individually.

Manninen and Engblom (2004) conclude on the University of Helsinki: "Therefore, the whole university is an 'adult education institution' in practice." Such a farreaching perspective is not to find at German universities. To the contrary, the establishment of new continuing education academies and universities (e.g. in Berlin) shows the trend to delegate the matter of continuing education to institutions outside of the university. But this trend appears to be an impasse since that way the constriction of the educational mandate of universities is stabilized. In an alternative approach at universities - in a lifelong learning approach - e-learning will play an essential role. Only with media-supported study forms the demand for flexible and individualized solutions can be covered. 


\section{Bibliography}

Bloch, R. (2006). 'Wissenschaftliche Weiterbildung im neuen Studiensystem Chancen und Anforderungen. Eine explorative Studie und Bestandsaufnahme', Wittenberg, Martin-Luther-University, Institute for Higher Education Research Wittenberg

DGWF-Empfehlungen (2005). 'Perspektiven wissenschaftlicher Weiterbildung in Deutschland aus Sicht der Einrichtungen an Hochschulen', Hamburg, German Society for Continuing Education and Distance Learning

Faulstich, P. (2003). 'Weiterbildung: Begründungen lebensentfaltender Bildung', München, Oldenbourg Wissenschaftsverlag Publisher

Geldermann, B. and Schade, S. (2007). 'Länderstudie Groß Britannien', in A. Hanft and M. Knust (eds), Internationale Vergleichsstudie zur Struktur und Organisation der Weiterbildung an Hochschulen. Oldenburg, Carl-von-OssietzkyUniversity, pp. 284-346

Hanft, A. and Knust, M. (eds). (2007). 'Vermarktung von Hochschulweiterbildung: Theorie und Praxis', Münster, Waxmann Publisher

Jongbloed, B. (2002). 'Lifelong learning. Implications for institutions', Higher Education, 3/4/2002, pp. 413-431

Kellermann P. (1991). 'Studienmotive und Arbeitsperspektiven '90: Ein Forschungsbericht', in H. Guggenberger, Hochschulzugang und Studienwahl: Empirische und theoretische Ergebnisse von Hochschulforschung. Klagenfurt

Kerres, M. and Stratmann, J. (2007). 'E-University: Zur systematischen Integration von IT-Anwendungen in Kernprozessen der Hochschule', in R. Keil, M. Kerres and R. Schulmeister (eds), E-University - Update Bologna. Education Quality Forum Bd.3. Münster, Waxmann Publisher, pp. 33-44

Kerres, M. and Nübel, I. (2005). 'The Status of E-Learning at German Higher Education Institutions', in U. Dittler (eds), E-Learning in Europe - learning Europe. Münster, Waxmann Publisher, pp. 29-50

Kerres, M. and de Witt, C. (2004). 'Pragmatismus als theoretische Grundlage zur Konzeption von e-learning', in H.O. Mayer (eds), Handlungsorientiertes Lernen und eLearning. München, Oldenbourg, pp. 77-100

Klink, C. (2001). 'Universitäre Bildung in der Öffnung für das lebenslange lernen: Der Beitrag der offenen Universität der Niederlande', Münster, Waxmann Publisher

Lahne, M. (2008). 'Mediales Lernen in Kanada und Deutschland', Saarbrücken, VDM-Publisher

Manninen, J. and Engblom, T. (2004). 'Adults in Finnish Higher Education', in R. Mark, M. Pouget and E. Thomas (eds), Adults in Higher Education. Learning form Experience in the New Europe. Oxford, pp. 121-132

Pechar, H. and Wroblewski, A. (1998). 'Non-traditional-Students in Österreich. Studienbedingungen bei Nebenerwerbstätigkeit, verspätetem Übertritt und alternativem Hochschulzugang', Final Report for the Ministry of Sience, Vienna

Röbken, H. (2007). 'Länderstudie USA', in A. Hanft and M. Knust (eds), Internationale Vergleichsstudie zur Struktur und Organisation der Weiterbildung an Hochschulen. Oldenburg, Carl-von-Ossietzky-University, pp. 403-447

Schuetze, H. G. (2005). 'Modelle und Begründungen lebenslangen Lernens und die Rolle der Hochschule - Internationale Perspektiven', in G. Wiesner and A. Wolter (eds), Die lernende Gesellschaft. München, Juventa-Publisher, pp. 225-244 
Winter, M. (2009). 'Das neue Studieren. Chancen, Risiken, Nebenwirkungen der Studienstrukturreform: Zwischenbilanz zum Bologna-Prozess in Deutschland', Wittenberg, Martin-Luther-University, Institute for Higher Education Research Wittenberg

Zawacki-Richter, O. and Reith, A. (2007). 'Länderstudie Finnland', in A. Hanft and M. Knust (eds), Internationale Vergleichsstudie zur Struktur und Organisation der Weiterbildung an Hochschulen. Oldenburg, Carl-von-Ossietzky-University, pp. 191-227

Zawacki-Richter, O. (2005). 'Einsatzkonzepte für E-Learning zur Integration in nachhaltige Supportstrukturen', in M.H. Breitner and G. Hoppe (eds), E-Learning. Einsatzkonzepte und Geschäftsmodelle. Heidelberg, Physica-Publisher HD, pp. $37-52$

www.hochschulkompass.hrk.de

\footnotetext{
${ }^{1}$ Structural guidelines for the federal states of Germany according to $\S 9 \mathrm{Abs} .2 \mathrm{HRG}$ for the accreditation of Bachelor- and Master Programs (decision of The Standing Conference of the Ministers of Education in Germany from 10.10.2003 in the form from 18.09.2008)

${ }^{2}$ s. http://www.e-learning.tu-darmstadt.de/elearning/konzept/index.de.jsp
} 